\title{
STUDIES ON IMPACT OF CONTAMINATION OF HEAVY METALS IN VRISHABAVATHI RIVER AND NEIGHBORING GROUND WATER
}

\author{
S.G. Ramachandraiah ${ }^{1}$, S.D.Venkataraja Mohan ${ }^{2}$ \\ ${ }^{I}$ Dr.Ambedkar Institute of Technology, Bangalore 560056, India \\ ${ }^{2}$ Dr.Ambedkar Institute of Technology, Bangalore 560056, India
}

\begin{abstract}
The perrineal source water stream contaminated with a large quantity of industrial,agricultural and domestic effluents. River Vrishabavati, a tributary of Arkavati which is a tributary of Cauvery flows in Bangalore south west taluk and carries a bulk of cities industrial effluents and domestic sewage. This polluted water use causes environmental issues in food chain contamination due to heavy metals. Water samples of both Vrishabavathi River and its surrounding ground water were collected and subjected to comprehensive analysis. Results of the study reveals that heavy metals were at the border level $C a, M g, B O D, C O D$ and solids exceeds its limits, further contamination of river stretch is to be immediatley prevented and remedies were given to restore the water quality of the affected river.
\end{abstract}

Keywords- Contamination, Effluents, Sewage, Quality, Ground Water

\section{INTRODUCTION}

The fresh water is of vital concerned for man kind since it is directly linked to human welfare water has wide used in irrigation, industrial and domestic uasage continues to increase where perrineal surface water source is absent the pollution of surface and ground water due to industrial and municipal waste is of rising concerns in many sub-urban, industrial concerns in Indiathough ground water is not get contaminated directly but once it occurs it is difficult to remediate[1]. Quality of ground water depends on geology of particular area and also varies with depth of water table and governed by extent and composition of dissolved salts depending upon source of salts and soil surface environment [2].

Long and sustain industrial activity near Vrishabavati river basin surroundings can offen need to ground water contamination, improper waste disposal practices gradually contaminated soils and entire ground water in that area the determintal alteration of naturally occuring physical thermal chemical or biological quality of ground water is works differently from surface water pollution virtually any activity where chemicals are waste may be released to the water body either intentially or accidentally has the potential to pollute the ground water. [3][4].

Ground water and surface water are interconnected if there is water supply well and near by ariver or stream near asource of contamination both will runs the risk of becoming contamination [5] [6].

The physical and chemical attributes of water are the critical components of water resources they include temperature dissolved oxygen, $\mathrm{pH}$, BOD, COD, TS, conductivity, hardness, turbidity,Alkalinity, Cloride , Flouride, Na, K, Ca, posphoate,sulphates, concentration of soluble and insoluble inorganic substances, $\mathrm{Ca}, \mathrm{Mg}, \mathrm{Cr}, \mathrm{Fe}, \mathrm{Cu}, \mathrm{Zn}, \mathrm{Ni}$, Total coliform and Feacol coliform are some of the parameters as per surface water disposal standards and an array of toxic substances which may have simple chemical properties but there dynamics may be complex in changing depending on other constituents in the geological strata, soils and land use in the region. [8][9][10].

\section{CASE STUDY}

The Arkavati River is ariver in India originating at Nandi hills of Chikkaballapur district and it is tributary of cauvery river joins at Kanakapura called "sangama" after flowing throughKolar'district and Bangalore rural district located in the south eastern part of India 12.90 north longitude and 77.56 east longitude.Its averge elevation from the sea is $920 \mathrm{~m}$ with in uneaven land scape of hill and valley to the south and relatively more level plateau towards the north. At present populations of Bangalore city is growing rapidly about six million and about to reach eight million by 2018 . The cities are facing acute water scarcity problem which is witnessed by increasing the gap between suply and demand. In the coming days providing the water would be a gigantic task, as there is no perrineal river and there are also there are also limitations for drawing the Cauvery river beyond 600 cusecs. .The Vrishabavati is a small river that flows of north of Bangalore city once used as a drinking watersource.Nandikeswara theertha kalyani (Basavatheertha) in front of Kadumalleswara temple at Malleswaram of Banagalore city is said to be the birth place of this river.Most of the sewage emanating from Bangalore is carried by these two rivers. Theriver has a stretch of 60 kms and it is dried up now and carries industrial effluents urban Sewage and improperly treated sewage water from treatment plant of Bangalore water supply and sewarage board. Just $15 \mathrm{~km}$ from Bangalore Vrishabavati river reduced to a cesspool. 


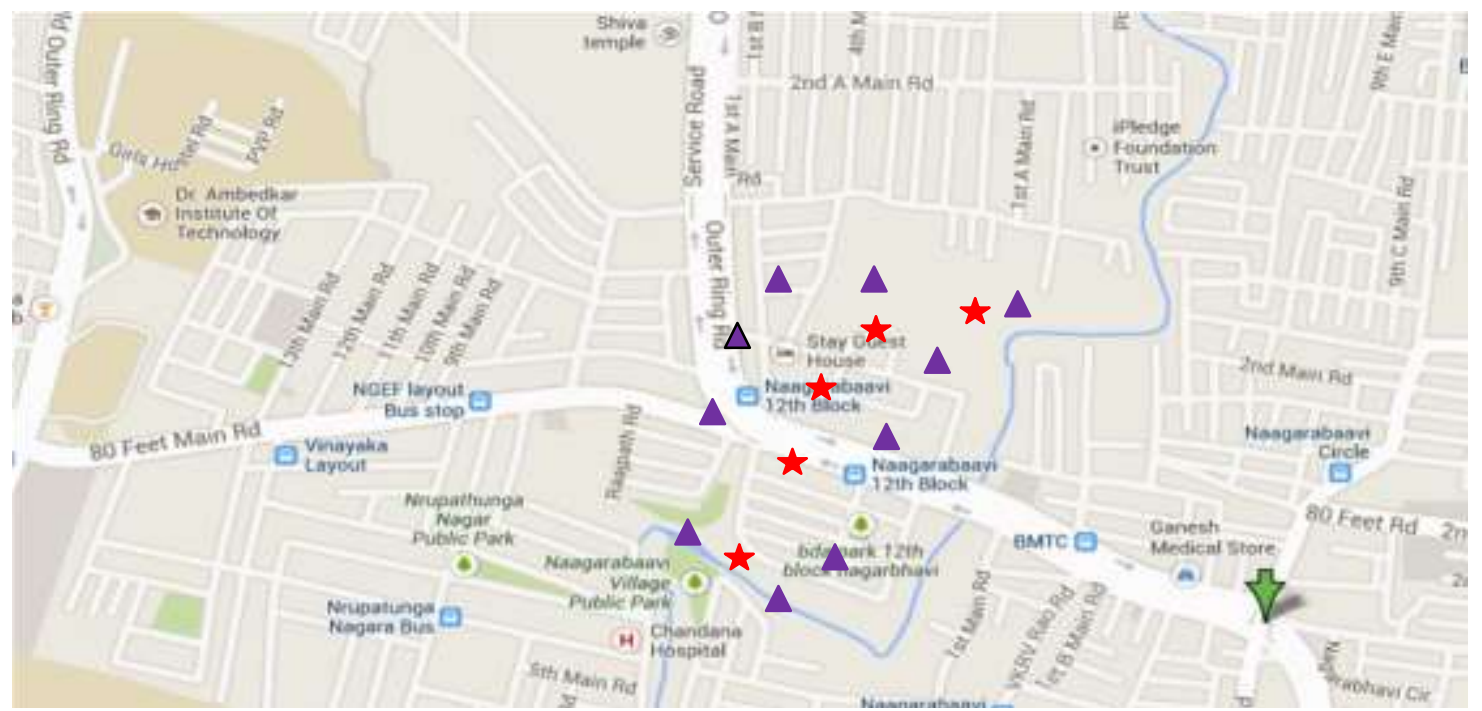

$--\hbar$ Waste water points

--- Ground water sample points

Fig.1 Map showing the Vrishabavathi River and sampling points.

Farmers suffer from skin alergy and cattle are infested with edema. Urban waste has contaminated ground water for a stretch of $2 \mathrm{kms}$. Villages in and around vrishabavati river are highly contaminated taking a toll on people's health cultivation and ecology. In the present attempt has been made to study the quality of Vrishabavati river water by analyzing various water quality parameters and monitoring the river quality. The polluted water was collected from Vrishabavati River situated near Jnanabharati campus Bangalore
University. Global positioning system (GPS) was employed to fix up the 10 number sampling locations for a stretch of 02 kilometers as shown in the map. Composite samples are obtained by mixing equal volumes of discrete equal grab samples to have an estimate of average water quality condition. Water samples were then subjected to various Physical and Chemical and Parameters and their values are comparerd with the water quality standards

\section{RESULTS AND DISCUSSION}

\subsection{Ground Water}

Table: 1 Ground water quality parameters for ten different locations

\begin{tabular}{|c|c|c|c|c|c|c|c|c|c|c|}
\hline Parameter & $\begin{array}{l}\text { GWS } \\
1\end{array}$ & $\begin{array}{l}\text { GW } \\
\text { S2 }\end{array}$ & $\begin{array}{l}\text { GWS } \\
3\end{array}$ & $\begin{array}{l}\text { GWS } \\
4\end{array}$ & $\begin{array}{l}\text { GWS } \\
5\end{array}$ & $\begin{array}{l}\text { GWS } \\
6\end{array}$ & $\begin{array}{l}\text { GWS } \\
7\end{array}$ & $\begin{array}{l}\text { GWS } \\
8\end{array}$ & $\begin{array}{l}\text { GWS } \\
9\end{array}$ & $\begin{array}{l}\text { GWS1 } \\
\text { 0 }\end{array}$ \\
\hline BOD & NIL & NIL & NIL & NIL & NIL & NIL & NIL & NIL & NIL & NIL \\
\hline DO & 7.3 & 6.8 & 7.05 & 6.7 & 6.95 & 7.3 & 7.1 & 6.85 & 7.1 & 7.3 \\
\hline Turbidity,NTU & 0.00 & 0.00 & 0.00 & 0.00 & 0.00 & 0.00 & 0.00 & 0.00 & 0.00 & 0.00 \\
\hline PH Value & 7.15 & 7.3 & 6.8 & 7.4 & 7.05 & 7.2 & 7.65 & 7.8 & 7.4 & 7.7 \\
\hline $\begin{array}{l}\text { Total Hardness as } \\
\mathrm{CaCO}_{3}, \mathrm{mg} / \mathrm{I}\end{array}$ & 600 & 500 & 460 & 430 & 450 & 470 & 540 & 480 & 520 & 490 \\
\hline Calcium as $\mathrm{Ca}, \mathrm{mg} / \mathrm{i}$ & 144 & 120 & 108 & 90 & 118 & 125 & 130 & 120 & 112 & 105 \\
\hline $\begin{array}{l}\text { Magnesium as } \mathrm{Mg}, \\
\mathrm{mg} / \mathrm{I}\end{array}$ & 57.4 & 48 & 45.6 & 35 & 40 & 55 & 50 & 40 & 44 & 35 \\
\hline Chloride as $\mathrm{Cl}, \mathrm{mg} / \mathrm{I}$ & $\begin{array}{l}177.2 \\
5\end{array}$ & $\begin{array}{l}116 . \\
35\end{array}$ & 101.85 & 120 & 141 & 135 & 153 & 128 & 140 & 155 \\
\hline $\begin{array}{l}\text { Total Dissolved } \\
\text { solids, mg/I }\end{array}$ & 850 & 740 & 610 & 700 & 720 & 680 & 780 & 650 & 670 & 660 \\
\hline $\begin{array}{l}\text { Sulphate as } \mathrm{SO4} \text {, } \\
\mathrm{mg} / \mathrm{I}\end{array}$ & 50 & 30 & 25 & 38 & 45 & 40 & 60 & 30 & 40 & 38 \\
\hline Nitrate as $\mathrm{NO3}, \mathrm{mg} / \mathrm{I}$ & 12 & 13 & 10 & 14.5 & 10 & 11 & 12 & 8.8 & 11 & 10.8 \\
\hline Fluoride as $\mathrm{F}$, $\mathrm{mg} / \mathrm{I}$ & 0.09 & 0.07 & 0.08 & 0.09 & 0.05 & 0,08 & 0.07 & 0.0 .5 & 0.07 & 0.08 \\
\hline Iron as $\mathrm{Fe}, \mathrm{mg} / \mathrm{I}$ & 0.08 & 0.1 & 0.07 & 0.11 & 0.06 & 0.05 & 0.09 & 0.06 & 0.08 & 0.05 \\
\hline $\begin{array}{l}\text { Chromium as Cr6+, } \\
\mathrm{mg} / \mathrm{I}\end{array}$ & $<0.05$ & $\begin{array}{l}<0.0 \\
5\end{array}$ & $<0.05$ & $<0.05$ & $<0.05$ & $<0.05$ & $<0.05$ & $<0.05$ & $<0.05$ & $<0.05$ \\
\hline Zinc as $\mathrm{Zn}, \mathrm{mg} / \mathbf{I}$ & $<0.1$ & $<0.1$ & $<0.1$ & $<0.1$ & $<0.1$ & $<0.1$ & $<0.1$ & $<0.1$ & $<0.1$ & $<0.1$ \\
\hline Copper as $\mathrm{Cu}, \mathrm{mg} / \mathrm{I}$ & $<0.05$ & $<0.0$ & $<0.05$ & $<0.05$ & $<0.05$ & $<0.05$ & $<0.05$ & $<0.05$ & $<0.05$ & $<0.05$ \\
\hline
\end{tabular}




\begin{tabular}{|l|l|l|l|l|l|l|l|l|l|l|}
\hline & & 5 & & & & & & & & \\
\hline $\begin{array}{l}\text { Manganese as Mn, } \\
\text { mg/I }\end{array}$ & $<0.1$ & $<0.1$ & $<0.1$ & $<0.1$ & $<0.1$ & $<0.1$ & $<0.1$ & $<0.1$ & $<0.1$ & $<0.1$ \\
\hline $\begin{array}{l}\text { Residual } \\
\text { Chlorine, mg/I Free }\end{array}$ & 0.04 & 0.02 & 0.03 & 0.05 & 0.04 & 0.03 & 0.06 & 0.03 & 0.05 & 0.05 \\
\hline $\begin{array}{l}\text { Total Alkalinity as } \\
\text { Caco3 Mg/l }\end{array}$ & 349.8 & 371 & 286 & 356 & 265 & 258 & 275 & 293 & 288 & 278 \\
\hline Lead & 0.04 & 0.02 & 0.01 & 0.03 & 0.02 & 0.04 & 0.01 & 0.03 & 0.01 & 0.05 \\
\hline
\end{tabular}

The experimental data of physicochemical parameters of water samples collected at different sites around and Vrishabhavathi river water is presented in tables 1 . Some of the parameters measured for ground water is tabulated in table 2 to 10 . The heavy metal concentration in Vrishabhavathi river water is presented in tables 2 .

The physical parameters and chemical parameters of ground water around Vrishabhavathi River are within the permissible limits as in BIS standards. Ground water samples collected such Ground water sample 1(GWS1), GWS2, GWS3, GWS4, GWS5, GWS6, GWS7, GWS8, GWS9 and GWS10 are parameters

(PH,Hardness,Alkalinity, $\mathrm{Ca}, \mathrm{Mg}, \mathrm{Cl}, \mathrm{TDS}, \mathrm{SO} 4, \mathrm{NO} 3 \mathrm{~F}, \mathrm{Fe}, \mathrm{Zn}, \mathrm{Cu}$, Mn,etc) shown in table no. 1 are tested as per IS 105001991.Ground water samples collected on either side of the Vrishabhavathi river at the interval of approximately $1 \mathrm{~km}$ from the sampling point. Samples collected in the upper streams shows higher concentration and decreases to some extend along the downstream of the river. The results of these groundwater samples shows that it is unfit for drinking and hence water should passed through RO system. Then it will be suitable for drinking.

Table 2. Wastewater quality parameter for Vrishabavathi river for five different locations

\begin{tabular}{|l|l|l|l|l|l|}
\hline Parameter & WWS1 & WWS2 & WWS3 & WWS4 & WWS5 \\
\hline BOD & 61.4 & 57.5 & 50.85 & 55.7 & 54.5 \\
\hline COD & 450 & 370 & 350 & 390 & 380 \\
\hline DO & 1.1 & 0.9 & 0.6 & 0.7 & 0.65 \\
\hline Turbidity,NTU & 12 & 9 & 15 & 13 & 10 \\
\hline PH Value & 7.4 & 7.5 & 7.7 & 7.3 & 7.6 \\
\hline $\begin{array}{l}\text { Total Hardness as CaCO } \\
\text { mg/I }\end{array}$ & 500 & 430 & 400 & 460 & 440 \\
\hline Calcium as Ca, mg/i & 112 & 88 & 64 & 95 & 90 \\
\hline Magnesium as Mg, mg/I & 52 & 45 & 38 & 48 & 46 \\
\hline Chloride as Cl, mg/I & 248.5 & 198.5 & 177.35 & 218.6 & 210 \\
\hline Total Dissolved solids, mg/I & 960 & 850 & 780 & 830 & 640 \\
\hline Sulphate as SO4, mg/I & 106.35 & 90 & 60 & 90 & 85 \\
\hline Nitrate as NO3, mg/I & 13 & 11 & 10.8 & 12 & 11.5 \\
\hline Fluoride as F, mg/I & 0.09 & 0.07 & $\mathbf{0 . 1 1}$ & 0.08 & 0.06 \\
\hline Iron as Fe, mg/I & 0.23 & 0.18 & 0.13 & 0.20 & 0.25 \\
\hline Chromium as Cr6+, mg/I & $<0.05$ & $<0.05$ & $<0.05$ & $<0.05$ & $<0.05$ \\
\hline Zinc as Zn, mg/I & $<0.1$ & $<0.1$ & $<0.1$ & $<0.1$ & $<0.1$ \\
\hline Copper as Cu, mg/I & $<0.05$ & $<0.05$ & $<0.05$ & $<0.05$ & $<0.05$ \\
\hline Manganese as Mn, mg/I & $<0.1$ & $<0.1$ & $<0.1$ & $<0.1$ & $<0.1$ \\
\hline $\begin{array}{l}\text { Residual Free Chlorine }, \\
\text { mg/I }\end{array}$ & 0.09 & 0.06 & 0.04 & 0.07 & 0.05 \\
\hline $\begin{array}{l}\text { Total Alkalinity as Caco3 } \\
\text { Mg/I }\end{array}$ & 371.5 & 385.6 & 408.5 & 345 & 368 \\
\hline LEAD & 0.05 & 0.03 & 0.08 & 0.04 & 0.05 \\
\hline
\end{tabular}

The BOD value at sampling Points wastewater sample 1 (WWS1), WWS2, WWS3, WWS4 and WWS5 are like 61.5, $57.5,50.85,55.7$ and $54.5 \mathrm{mg} / \mathrm{lit}$ and limit according to BIS standard and KSPCB limit is $30 \mathrm{mg} / \mathrm{lit}$, the data in Vrishabhavathi river water is higher at the sites. COD value at site numbers WWS1, WWS2, WWS3, WWS4 and WWS5 are 450,370, 350, 390, $380 \mathrm{mg} / \mathrm{lit}$ and limits not exceeding according to BIS and KSPCB limit is $250 \mathrm{mg} / \mathrm{lt}$.
Hence the water is unfit and it can be used for domestic, gardening, cleaning, washing etc only after the tertiary treatment of river water.

The level of chromium for all ten given samples of ground water remains same rhat is $0.5 \mathrm{mg} / \mathrm{l}$ as shown in figure 2 . 


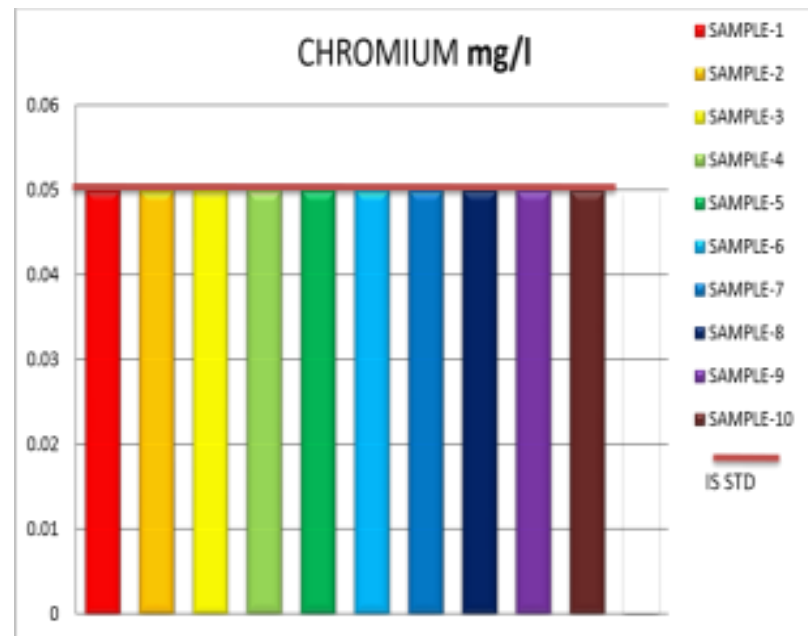

Fig.2 Spatial and Temporal variation of Chromium $(\mathrm{mg} / \mathrm{l})$

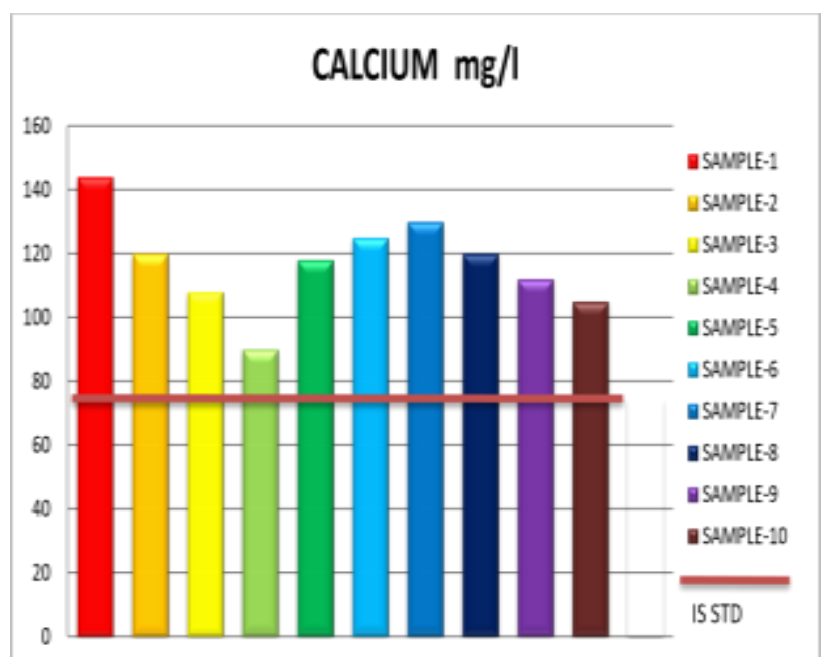

Fig.3: Spatial and Temporal variation of Calcium (mg/l)

The level of calcium is $140 \mathrm{mg} / \mathrm{l}$ for $1^{\text {st }}$ sample of ground water as shown in figure 3.

Page 4

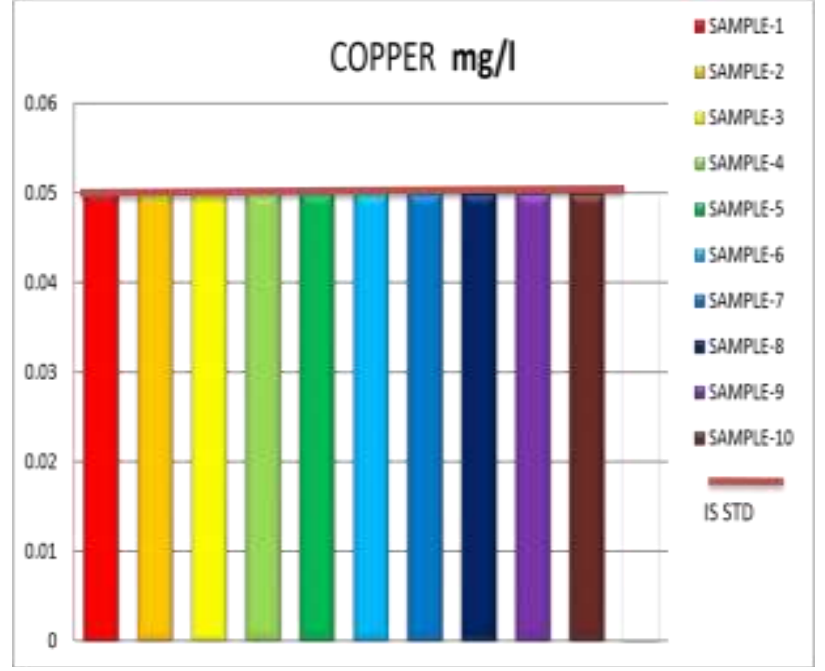

Fig. 4: Spatial and Temporal variation of Copper (mg/l) The level of chromium for all ten given samples of ground water remains same rhat is $0.5 \mathrm{mg} / \mathrm{l}$ as shown in figure 4 .



Fig.5 Spatial and Temporal variation of Magnesium mg/l

As shown in the fig.5 all the sample exeeds the Indian standard limit of $30 \mathrm{mg} / \mathrm{l}$ indicating the magnesium contamination.

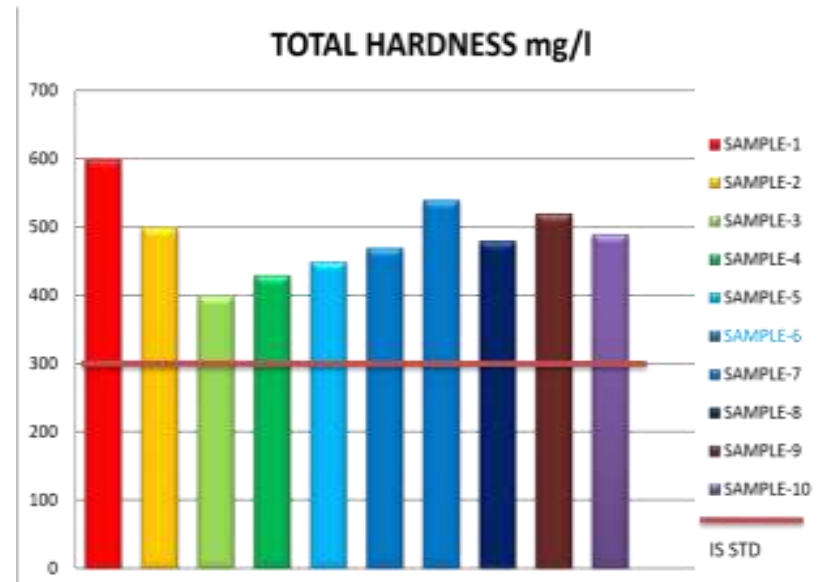

Fig.6: Spatial and Temporal variation of total hardness $\mathrm{mg} / \mathrm{l}$

Total hardeness exeeds standard limit of $300 \mathrm{mg} / \mathrm{l}$ which is indicated as maximum hardness as shown in fig.6. Sample one has reached $600 \mathrm{mg} .1$ indicating presence of carbonate and bicarbonate ions.

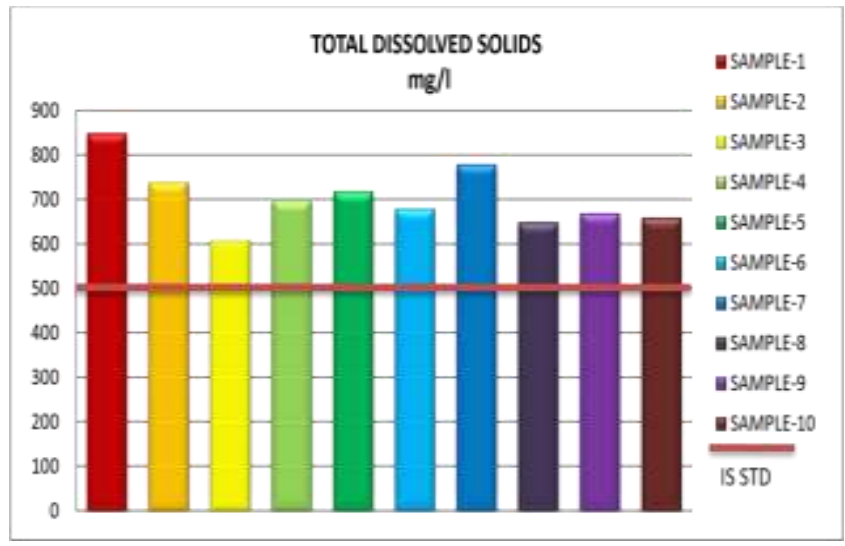

Fig7: Spatial and Temporal variation of T D S mg/l

Total dissoloved solids has exeeds the standard limit of 500 $\mathrm{mg} / \mathrm{l}$ for all samples as shown in figure 7 indicating various organic and inorganic solids. 


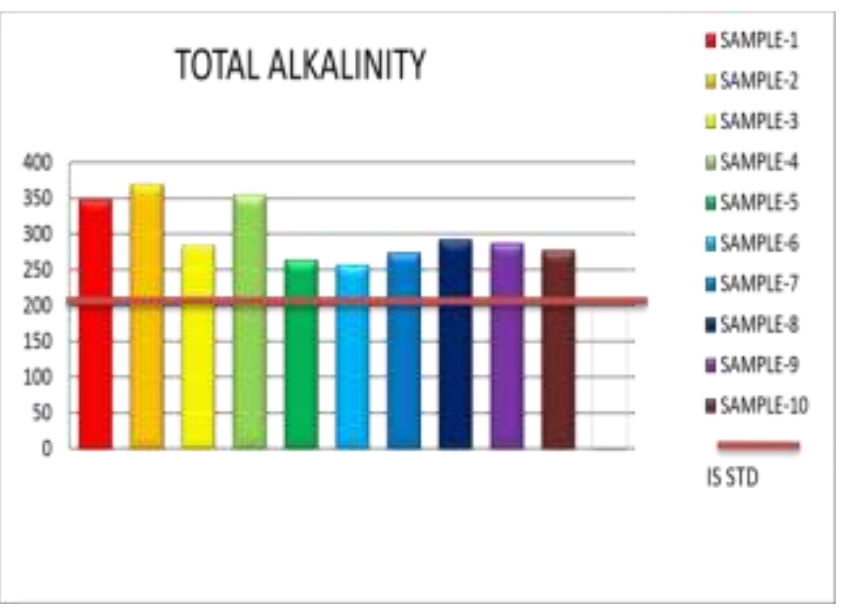

Fig.8: Spatial and Temporal variation of Total Alkalinity $\mathrm{mg} / \mathrm{l}$

Total alkalinity exeeds the tolerance limit as shown in figure 8 indicating presence of salts hydroxyl ions as water pollitants.

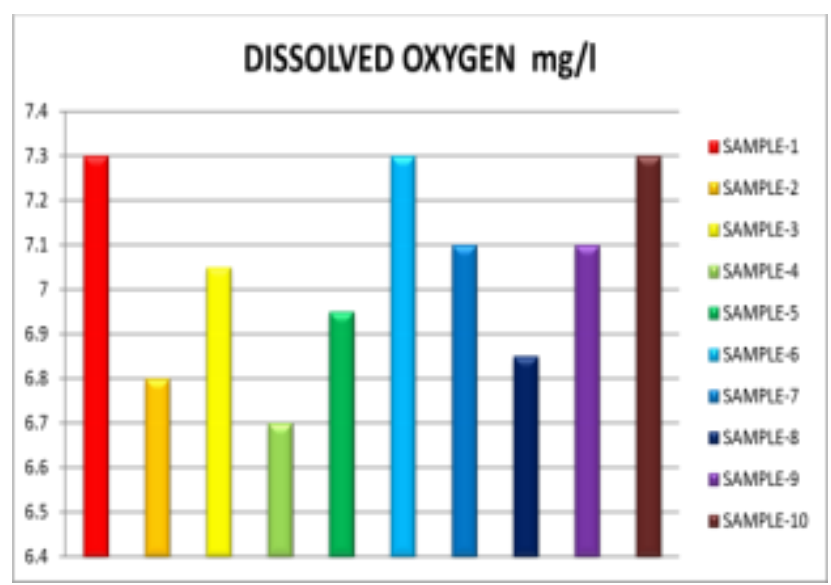

Fig.9 Spatial and Temporal variation of Dissolved Oxygen $\mathrm{mg} / \mathrm{l}$

Dissolved oxygen which is essential for any aquatic life is maintained for sample 1,6 and $10 \mathrm{~m}$ rest of the sample shown dificit of dissoloved oxygen as shown in figure 9 .



Fig.10 Spatial and Temporal variation of Manganese mg/l The level of Manganese for all ten given samples of ground water remains same that is $0.1 \mathrm{mg} / \mathrm{l}$ as shown in figure 10 .

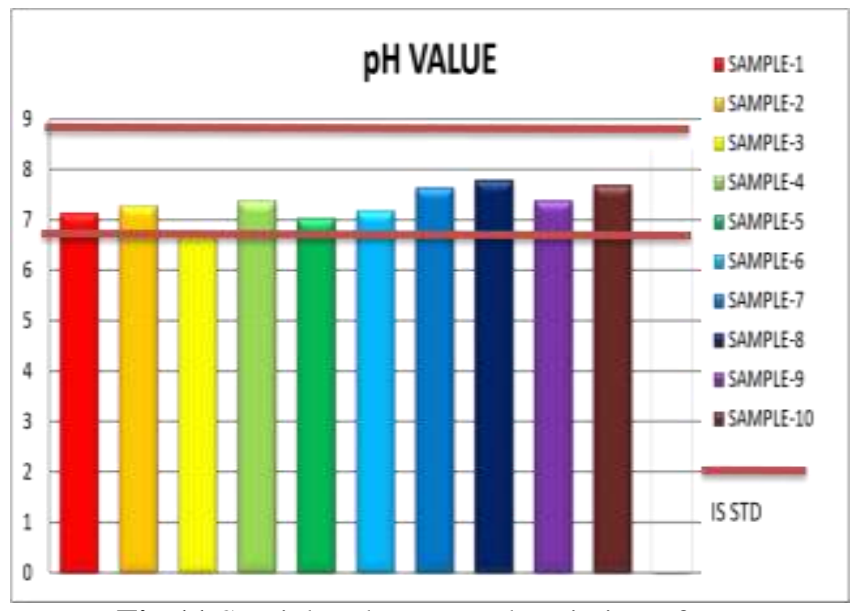

Fig.11 Spatial and Temporal variation of $\mathrm{pH}$

The $\mathrm{pH}$ value for drinking water should be 6.5 to 8.5 . However all the samples were shown moderate varation in $\mathrm{pH}$ of that of drinking water.

\subsection{Wastewater Samples}

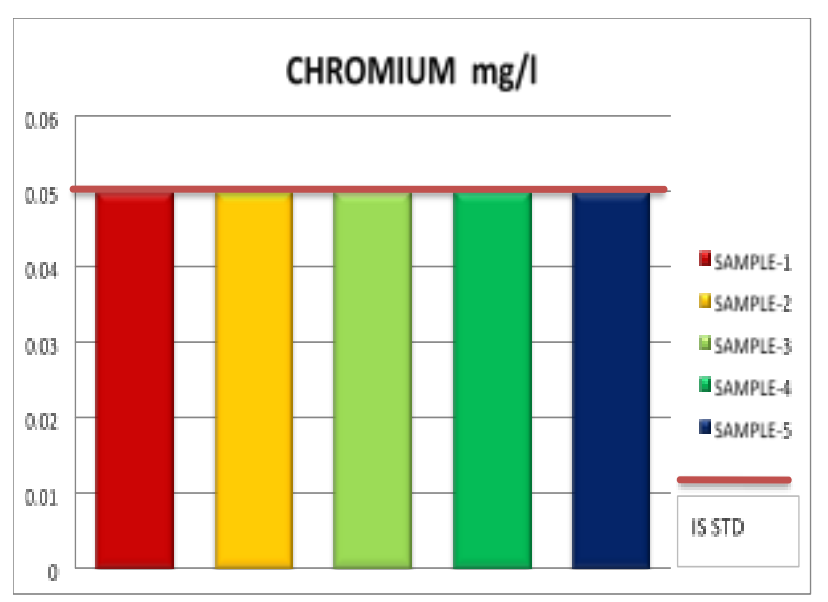

Fig.12 Spatial and Temporal variation of Chromium mg/l

The chromium level is samefor all 1 samples that is 0.05 $\mathrm{mg} / / \mathrm{l}$ as shown in figure 12 indicating it is at the border level.

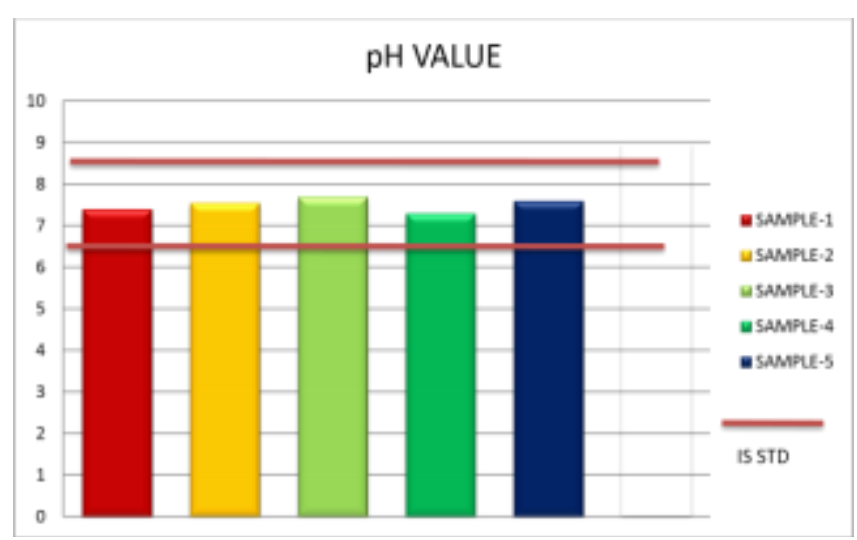

Fig.13 Spatial and Temporal variation of $\mathrm{pH}$

The $\mathrm{pH}$ value for drinking water should be 6.5 to 8.5 . However all the samples were shown moderate varation in $\mathrm{pH}$ from that of drinking water and slightly alkaline. 


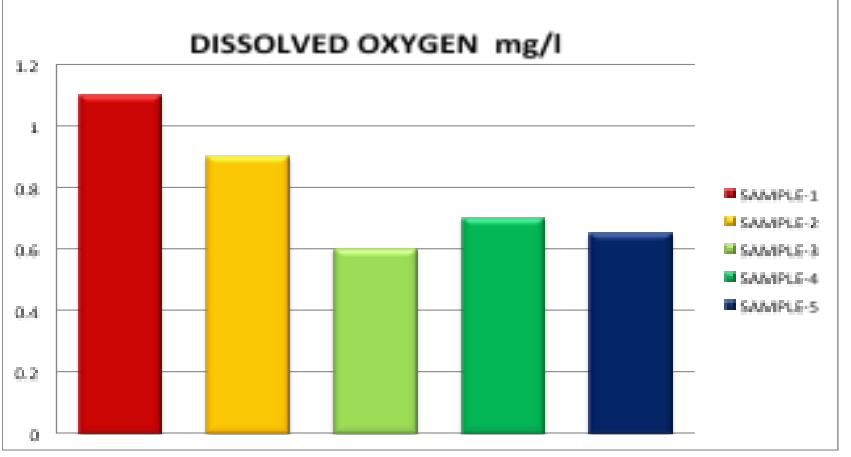

Fig.14 Spatial and Temporal variation of Dissoloe Oxygen

Dissolved oxygen which is essential for any aquatic life is fully dificit and found $1 \mathrm{mg} / \mathrm{l}$ maximum indicating the wastewater is septic at Vrishabavathi River

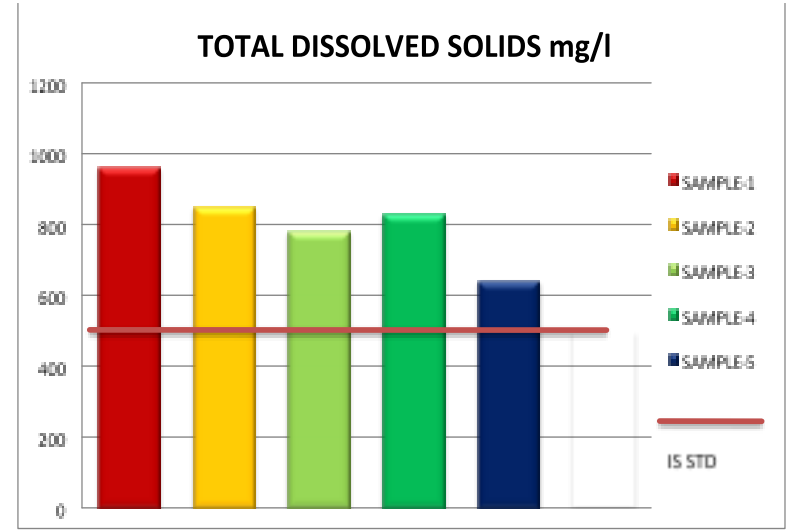

Fig.15 Spatial and Temporal variation of Total Dissolved Solids mg/l

Total dissolved solids exeeds standard limit of $500 \mathrm{mg} / \mathrm{l}$ for all samples and indicating the presence of dissolved solids which gives color to wastewater.

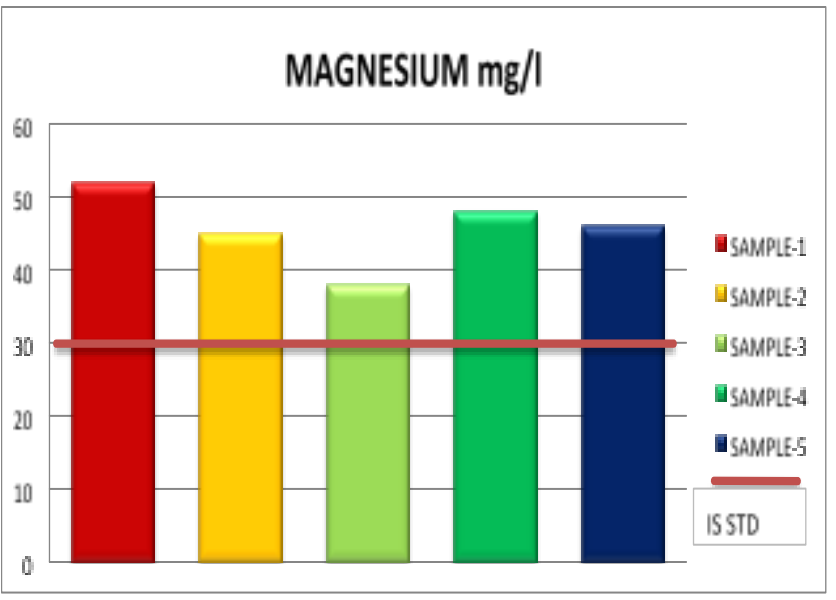

Fig.16 Spatial and Temporal variation of Total Magnesium $\mathrm{mg} / \mathrm{l}$

Magnesiuim which is a metal, exeeds the standard limit of $30 \mathrm{mg} / \mathrm{l}$ as shown in figure 16.for all samples.

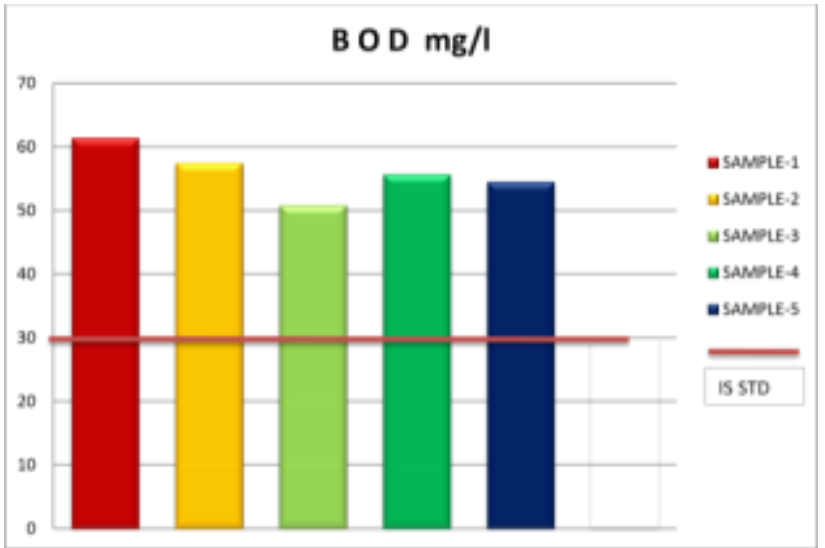

Fig.17 Spatial and Temporal variation of Total Dissolved Solids mg/l

Biochemical Oxygen demand is directly an effluent quality indicator exceeds standard limit to be disposed to open water that is $30 \mathrm{mg} / \mathrm{l}$ indicating the Vrishabavathi river is highly polluted.

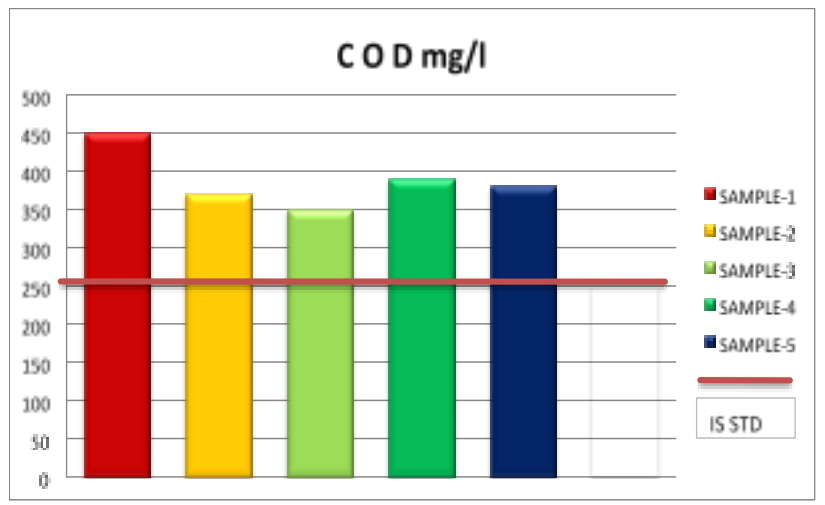

Fig.18 Spatial and Temporal variation of Total COD mg/l

The Chemical Oxygen demand (COD) is exeeds the standard limit of $250 \mathrm{mg} / \mathrm{l}$ indicating more chemicals are required to oxidise the organic matter as shown in the figure 18.



Fig.19 Spatial and Temporal variation of Total Turbidity $\mathrm{mg} / \mathrm{l}$

The level of Turbidity is exeeds the standard limit of $5 \mathrm{mg} / \mathrm{l}$ as shown in figure 19 indicating penetration of light is not possible due to increase in total solids. 


\section{CONCLUSION}

- It can be concluded that rapid population growth and industrialization have brought about resource degradation and a decline in environmental quality.

- Ground water around Vrishabhavathi River shows both physical and chemical parameters are within the permissible limits. Even though it is not directly suitable for drinking and it is suitable drinking only after water is passed through RO system.

- The analysis of Vrishabhavathi river water samples reveals that the water is highly contaminated at selected points which are not suitable for drinking and irrigation.

- BOD, COD and Turbidity concentration is above permissible limit. Even though the other metal concentration is below permissible limit, it is necessary to prevent excessive buildup of these pollutants which are transferred to soil and finally food chain.

- In irrigation tube well water can be used to dilute the heavy metal concentration of river water.

\section{REFERENCES}

[1]. Water Supply and Sanitary Engineering - Santhosh K Garg , Khanna publishers 2008

[2]. Water Supply Engineering - BC Punmia and Ashok Jain, 2010

[3]. International Journal of Scientific \& Engineering Research Volume 4, Issue 1, January2013 ISSN 2229-5518, pp.1-4

[4]. Studies on heavy metals contamination in Vrishabhavathi river water and ground water of the surrounding river( Jayadev, E.T. Puttaih, International Journal of Scientific \& Engineering Research Volume 4, Issue 1, January-2013 ISSN 2229-5518. pp.1-9

[5]. H. Lokeshwari and G.T. Chandrappa., Impact of heavy metal contamination of Bellandur Lake on soil and cultivated vegetation. Current Science, 91: 622 - 627, (2006).

[6]. Diversification of agriculture for human nutrition U.N. Joshi and Y.P. luthra, current science, vol. 78, no. 7, 10 april 2000

[7]. M.V.Ahipathy ,E.T. Puttaiah , Ecological characteristics of Vrishabhavathi river in Bangalore(India), Environ Geol,49: 1217-1222, (2006).

[8]. Ambient Freshwater and Effluent sampling - Her Majesty the Queen in Right of the Province of British Columbia 2003 report (All India rights reserved)

[9]. R.C.Tiwari, P.K.Saraswat and H.P.Agarwal, Changes in micronutrients status of soils irrigated with treated sewage water and tube well water, Journal of Indian society of soil science 51, pp.150-155, (2003)

[10]. Manoj Kumar Meena, Subroto Dutta, Rashmi Pradhan, EJEAF Che.9 (4), 760-766, (2010).

[11]. $\quad$ www.citefactor.org/.../Studies $\% 20$ on\%20heavy\%20metals\%20contamina.tion 